ISSN: 2316-6517

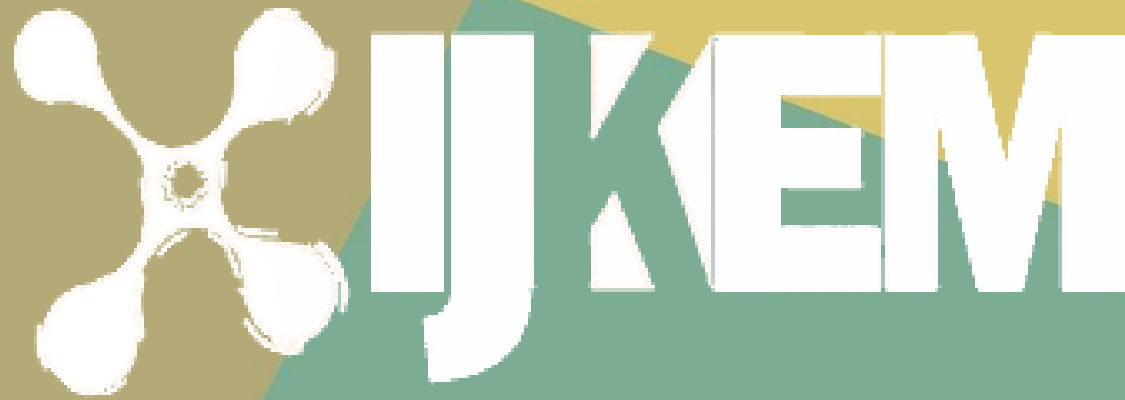

International Journal of Knowledge Engineering and Management

v. 9, n. $25,2020$.

(c) (1) (8)

ijkem.ufsc.br 
Florianópolis, v. 9, n. 25, p. 06-30, 2020.

- ISSN 2316-6517 •

- DOI: 1047916 •

\title{
IMPLICIT BIAS AND CULTURAL COMPETENCE: A FRAMEWORK FOR ENHANCING TACIT KNOWLEDGE TRANSFER
}

\author{
MANAR ALSAID \\ Ph.D. Graduate Student \\ University of North Texas (UNT) \\ Manaralsaid@my.unt.edu \\ ORCID: 0000-0002-8172-032X \\ SULIMAN HAWAMDEH \\ Ph.D. in Information Science \\ University of North Texas (UNT) \\ Suliman.hawamdeh@unt.edu \\ ORCID: 0000-0001-7018-6945 \\ BOBBIE SARTIN LONG \\ Ph.D. in Information Science and Learning Technologies \\ Emporia State University (ESU) \\ blong6@emporia.edu \\ ORCID: 0000-0002-8807-9221
}

Submissão: 26/11/21. Aceitação: 06/12/21.

Sistema de avaliação: duplo cego (double blind review). UNIVERSIDADE FEDERAL DE SANTA CATARINA (UFSC) 


\section{PRECONCEITOS IMPLÍCITOS E COMPETÊNCIA CULTURAL: UMA ESTRUTURA PARA APRIMORAR A TRANSFERÊNCIA DE CONHECIMENTO TÁCITO}

\section{Resumo}

Objetivo: $O$ trabalho neste artigo visa desenvolver uma estrutura conceitual e prática que considera as questões culturais e estruturais que afetam o trabalho de policiamento, como o preconceito implícito, a competência cultural e a transferência de conhecimento tácito.

Design | Metodologia|Abordagem: O desenvolvimento da estrutura conceitual proposta baseia-se na revisão sistemática da literatura e no exame e adaptação de trabalhos anteriores que tratam de questões culturais e estruturais que contribuem para o preconceito implícito no trabalho de policiamento. A validação do modelo proposto é parte de uma pesquisa de métodos mistos em andamento, que usa dados quantitativos e qualitativos para avaliar o papel mediador da competência cultural, treinamento de transferência de conhecimento tácito.

Resultados: Os resultados preliminares da análise de conteúdo da literatura recuperada do Google Scholar e Web of Science mostraram muito pouca sobreposição entre os estudos em termos dos conceitos que conectam os conceitos viés implícito, competência cultural e transferência de conhecimento tácito. O modelo proposto adota uma abordagem holística e integrada para lidar com questões culturais e estruturais que afetam o trabalho de policiamento. É necessário coletar dados mais aprofundados usando métodos mistos de pesquisa para poder tirar conclusões significativas. A tecnologia como um facilitador pode ser usada para facilitar a comunicação e aprimorar o processo de transferência de conhecimento tácito. $O$ trabalho policial é complexo e requer indivíduos altamente treinados com um espectro de habilidades e competências, incluindo competência cultural

Originalidade |Valor: Um dos problemas com questões sociais e culturais que afetam 0 policiamento é a falta de estudos que adotem uma abordagem holística e integrada para o problema do preconceito implícito. Os fatores de competência social e cultural são considerados componentes vitais do trabalho policial e precisam ser integrados ao treinamento para o trabalho policial.

Palavra-chave: Consciência cultural. Competência Cultural. Preconceito Implícito. Uso da Informação. Gestão do Conhecimento. Transferência de conhecimento. Diversidade racial e cultural. Transferência de conhecimento tácito. 


\section{IMPLICIT BIAS AND CULTURAL COMPETENCE: A FRAMEWORK FOR ENHANCING TACIT KNOWLEDGE TRANSFER}

\section{Abstract}

Objective: The work in this paper aims at developing conceptual and practical framework that considers cultural and structural issues affecting policing work such as implicit bias, cultural competence, and tacit knowledge transfer.

Design|Methodology|Approach: The development of the proposed conceptual framework is based on systematic review of the literature and close examination and adaptation of previous work dealing with cultural and structural issues contributing to implicit bias in policing work. The validation of the proposed model is part of an ongoing mixed methods research using both quantitative and qualitative data to assess the mediating role of cultural competence, training tacit and knowledge transfer.

Results: Preliminary results from the content analysis of the literature retrieved from Google Scholar and Web of Science showed very little overlap among studies in terms of the concepts connecting the concepts implicit bias, cultural competence and tacit knowledge transfer. The proposed model adopts a holistic and integrated approach in dealing with cultural and structural issues affecting policing work. There is a need for gathering more indepth data using mixed methods research to be able to draw meaningful conclusions. Technology as an enabler can be used to facilitate communication and enhance tacit knowledge transfer process. Police work is complex and requires highly trained individuals with a spectrum of skills and competencies including cultural competence

Originality | Value: One of the problems with social and cultural issues affecting policing is the lack of studies adopting holistic and integrated approach to the problem of implicit bias. Social and cultural competence factors are considered vital components of police work and need to be integrated into police work training.

Keywords: Cultural Awareness. Cultural Competence. Implicit Bias. Information Use. Knowledge Management. Knowledge Transfer. Racial and Cultural Diversity. Tacit Knowledge Transfer. 


\section{Introduction}

Increased interest in implicit bias and cultural competence in policing recently can be attributed to current events the fact that research findings are supporting the notion that implicit bias does exist (Greenland et al.,1998); (Eberhardt et al., 2004); (Wilson et al., 2017). Implicit bias is where unconscious attitudes, stereotypes, and perceived concepts can impact one's actions. The development of the Implicit Association Test (IAT) and its wide use has created more awareness and recognition of the existence of implicit bias. The controversial IAT developed by a team of researchers to measure the strength of association between certain concepts, judgments/evaluation, and stereotypes. The test is designed to detect the strength of one's subconscious in which faster responses are viewed as more strongly associated in one's memory and subconscious than slower responses (Fridell, 2008); (Spencer et al., 2016). People normally do not like to be told that they are biased, or their action might have been influenced by preconceived concepts or stereotypes, especially if they are acting within organizational policies and guidelines. The lack of alignment between one's own values and beliefs and those of the organization can blur the overall picture and lead to misinterpretation of rules regardless of context. For one to recognize their self-implicit bias, they must demonstrate a certain level of self-awareness as well as a greater social and cultural competence. Social and cultural competence is defined as the ability to understand, appreciate, and interact with people of different cultures and recognize the significance of culture in one's own life and in the lives of others (Montiel-Overall, 2009); (Shuntay et al., 2020).

Recent events in the U.S. related to policing and social justice have brought to the public's attention racial issues that, even though not new, they are part of repeated incidents exposing the excessive use of force by law enforcement when dealing with minorities. George Floyd's case brought this issue into the spotlight because videos captured by bystanders shocked and ignited protests around the world. It highlighted the depth of the racial problems and the importance of passing social justice legislation and other policies to address and minimize systemic racism. However, issues such as implicit bias, systematic and institutional bias are deep seated in the culture, values, and belief at both the individual and organizational level. The science behind implicit bias, cultural 
competence, and organizational development suggests that education and training programs aimed at creating awareness, enhancing cultural competencies, and promoting effective tacit knowledge transfer are critical in supporting and enacting legislations.

According to the National Police Foundation, about half of all officers in the U.S. have a two-year degree, and only 30\% hold a four-year degree (Gardiner, 2017). In most communities, police officers are not required to have higher education. In fact, in many areas of the U.S., the minimum police education requirements are a high school diploma and attendance at a six-month long police academy. Although the education level of police officers is rising, in select U.S. precincts where $100 \%$ of the officers have bachelor's degrees and $5 \%$ have master's degrees, there is increased professionalization of the law enforcement field (Burnett et al., 2012).

The level of complexity in policing work stems from the need to demonstrate high level of authority and toughness and at the same time show a great deal of understanding, passion, and fairness. The existence of implicit and racial bias can further complicate the job and make it difficult to separate preconceived beliefs and stereotypes from situation. The main research question in this study is focused on the relationship between implicit knowledge, cultural competence, and tacit knowledge transfer. Can effective tacit knowledge transfer lead to behavioral change, improved cultural competence and in return minimizing the impact of implicit bias in police work.

\section{Literature Review}

Implicit bias refers to one's action that could be impacted by unconscious attitudes, stereotypes, and misrepresented reality (Eberhardt et al., 2004); (Wilson et al., 2017). In a police context, a police officer might perceive that a certain group of people, for example, are more likely to be violent than others based on certain deep-rooted stereotypes or unconscious attitudes. Studies related to implicit bias in policing are gaining momentum given the recent events and the increased use of video evidence of police actions. According to Russell-Brown (2018), a list of the well-known cases includes Sandra Bland, Michael Brown, Philando Castile, Stephon Clark, Sam DuBose, Eric Garner, Laquan McDonald, Tamir Rice, and Walter Scott. These well-known cases 
have sparked national interest in understanding the role of implicit bias in policing and how cultural competence could be used to deal with the problem. The recent event involving the death of George Floyd ignited protests around the word after the public were able to watch videos recorded of the use of excessive force by a police officer. The videos left many wondering about the real motives behind the police officer's action and whether anything could have been done to save George Floyd's life. Many wondered whether other police officers present could have done something different to avoid the tragic incident. It is unclear the degree by which other types of structural and institutional bias contributed to the problem. In a recent study Worden et al. (2020) demonstrated that even though attitudes shift following implicit bias training, racial and ethnic disparities remained implying that particular implicit bias training did not lead to behavioral change.

Studies related to the use of knowledge management practices in police work may offer insight into some of the social and cultural issues at both the individual and organizational level that might impact behavioral change. The degree to which knowledge sharing and knowledge transfer happen in training might give us an idea about the capacity and willingness to learn (Luen and Al-Hawamdeh, 2001); (Abrahamson and Goodman-Delahunty, 2014); (Rosellini and Hawamdeh, 2020); (Cotter, 2017); (Fathi et al., 2011). Bransford (2012) discussed five major factors that affect information and knowledge transfer such as trust, internal influence, community policing, external influence, and complexity. Trust is a primary factor that must be established for effective communication and knowledge transfer (Seba and Rowley, 2010). Cotter (2017) reported that $93 \%$ of the intelligence officers relied on informal channels of exchanging intelligence information. This could be attributed to the lack of trust in formal and official channels. Officers indicated they would not share information with an intelligence officer they did not know and trust.

Another important factor that could affect sharing of information and knowledge is the political environment and the fact that "knowledge-sharing could give rise to conflict, especially when it involves new ideas that could be controversial" (Seba and Rowley, 2010. p. 615). This normally undermines the level of trust in the organization and leads to knowledge hoarding. According to Fathi et al., (2011) information and knowledge hoarding is a common phenomenon when the environment in an organization is highly political and competitive. It is only when the level of trust between employees improves, and employees do not see each other as a threat that they start to adopt 
positive attitudes towards knowledge sharing and knowledge transfer. Information exchanged by senior police officers is perceived to be more reliable, more current, and more secure (Cuttor, 2017). Police officers may have a difficult time-sharing knowledge since "perceptions of risk and barriers inhibited or interrupted knowledge sharing" (Seba and Rowley, 2010, p. 615). However, studies found that appropriate connectivity and well-managed networks within organizations positively impacted performance learning and innovation so that officers were more comfortable sharing ideas and resources (Fathi et al., 2011).

Research in information management, information culture, and information use show that information's usefulness or value is not only based on how well the information matches the query or the subject matter, but also the norms, practices and requirements imposed by the organization (Choo et al., 2006). Information use can vary from one person to another and from one organization to another. For information to be effectively used, information must first make sense within the environment and only then be communicated effectively through an effective knowledge transfer process (Dervin, 1983). Various studies have discussed the importance of information-use and knowledge transfer in police work and recommended different knowledge management practices such as mentoring, apprenticeship, and storytelling. Storytelling can be an effective method of knowledge sharing and knowledge transfer within police work. Criminal justice stories allow experienced officers to share knowledge with less experienced colleagues. (Burnet et al., 2012) found that storytelling fell into four categories: personal storytelling, venting/therapy, inspiring, and conveying external news and served the purpose of educating, documenting life, and making sense of police culture and police leadership.

Culture at the individual and organizational level plays a big role in shaping people's thinking, mental models, and assumptions about themselves and about others. Culture influences perception as to who is knowledgeable and shapes behavior and attitudes towards other cultures and across jurisdictions. The stronger the cultural context supporting friendship, behavior, and recognition, the more likely people will share resources and engage in information and knowledge sharing activities (Fathi et al., 2011); (Seba and Rowley, 2010); (Plecas et al., 2011). Cynicism can impact knowledge sharing and cultural sensitivity. In law enforcement, cynicism takes the form of organizational cynicism as well as cynicism towards outsiders (Torres et al., 2018). For example, in Ferguson, Missouri, unrest took place during August 2014 after a fatal 
shooting of an unarmed person by police and still impacts the community today. Torres et al. (2018) explains that "post-Ferguson psychological impacts continued to affect current levels of cynicism, motivation, and apprehensiveness".

There are legitimate reasons for resistance to knowledge sharing among law enforcement agencies. Privacy and confidentiality are real concerns, specifically surrounding liability, legal, or civil rights, medical, or social concerns (Plecas et al. 2011). Trust plays a primary role when police are interacting with marginalized populations. Community policing programs should be rooted in trust, but sometimes trust-based relationships are hard to establish when police face significant reform challenges or engage in certain activities that might be human rights violations (Holmer and Deventer, 2014). Diversity representation and being culturally sensitive are essential components of community policing. Female police officers were found to be more responsive to the needs of women in a community and were able to address security more directly, especially in cases of sexual crimes, domestic violence, sex abuse, and assault (Holmer and Deventer, 2014). When policing ethnic and racial groups, sustained community engagement with a clear commitment to build strong interpersonal relationships are as important as police ethnic representation. Community policing programs can generate trust by providing decentralized and effective security, transparency, and accountability through local and inclusive participation from the community (Holmer and Deventer, 2014).

Organizational culture (associated with certain beliefs, values, and attitudes) can be an important factor in either facilitating the flow of information and knowledge sharing or act as a barrier to improving knowledge sharing. Studies have shown that despite the police force's efforts to encourage employees to share knowledge, none of the cases studied had an integrated or formal strategy for sharing knowledge or facilitating the flow of information (Seba and Rowley, 2010); (Curry and Moore, 2003). Many of these efforts do not take into consideration the complex nature of the knowledge sharing process. According to Abrahamson and Goodman-Delahunty (2014), free flow of information in contemporary policing is a subject of accessibility, politics, security, and information context. A study by Cotter (2017) found an overreliance on informal personal communication networks was a means to facilitate multi-jurisdictional information sharing. Information shared through personal connections is deemed more current and 
more accurate, which highlights the importance of social networks and personal connections in intelligence work.

Studies related to police training and the implementation of knowledge management practices have shown that for learning to occur, first participants must have the capacity to learn and second must have the willingness to learn and engage in a meaningful learning process (Luen and Al-Hawamdeh, 2001); (Goodman-Delahunty, 2014). For effective knowledge transfer and behavioral change to take place in training, cultural and organizational issues must be addressed and measured to assess the outcome of trainings (Rosellini and Hawamdeh, 2020). Braga and Weisburd (2006) reviewed and discussed community policing initiatives from 1980 - 2000 in the U.S. such as broken windows policing, problem-oriented policing, hot spots policing, and evidencebased policing. While many of these initiatives did result in crime reduction, the challenge remained in building community of trust and changing public perceptions of policing (Telep and Weisburd, 2012). Additionally, studies demonstrate that diversity training alone without assessing the level of learning and knowledge transfer do not necessarily influence real behavior and the racial attitudes of police officers (Schlosser, 2013); (Zimny, 2015; Coon, 2016).

\section{Design/ Methodology}

The development of the conceptual model is based on the systematic review of the literature using content analysis and adaption of models developed in previous studies. Clustering and categorization are used to identify major concepts and variables related to cultural and structural issues affect policing work, implicit bias, cultural competencies, and tacit knowledge transfer. The proposed framework in Figure 3 is based on work developed by Luen and Al-Hawamdeh (2001) and Choo et al. (2006).

The proposed conceptual framework focuses on the cultural and structural issues affecting attitude, capacity, and willingness to engage in meaningful tacit knowledge transfer activities. It is hypothesized that evidence of tacit knowledge transfer activities can lead to actual behavior and behavioral change leading paving the way for the development of a more effective cultural competence. 
The validation of the proposed model along with the hypothesis will be carried out as part of an ongoing research using mixed methods approach in the form of quantitative and qualitative instruments. Preliminary results of content analysis of the literature retrieved from Google Scholar and Web of Science using query terms such as implicit bias, racial bias, cultural bias, systematic bias, diversity and inclusion, highlighted the need for gathering more data using holistic and integrated investigations when addressing implicit bias and cultural competence.

\section{Conceptual Framework and Discussion}

Knowledge management concerns itself with the knowledge processes and practices dealing with data, information, and knowledge lifecycle. Knowledge management enables us to look at the big picture and use a holistic approach to dealing with complex issues such as implicit bias in policing work. Black Lives Matter has highlighted the existence of systemic problems in police work and renewed interest in examining social and cultural issues such as diversity, equity, and inclusion. In turn, this has renewed interest in studies about implicit and cultural bias which will hopefully enhance cultural competence. But despite the increase in implicit bias training, there are still limited studies in the effectiveness of such training. A recent study by the NYPD about implicit bias training indicated that despite attitudes of police officers are shifting post implicit bias training, racial and ethnic disparities remained unchanged (Worden et al., 2020). Training is an important activity in most organizations and considered a critical investment. Using accurate measures to assess the effectiveness of training is critical to the intended goals of the training and eventually must result in behavioral changes.

There are several training evaluation models cited in the literature including the Kirpatrick model, CIRO model, Brinkerhoff model and Kaufman model. Kirkpatrick's model is one of the most popular models used to assess learning outcomes such as skill, knowledge, and attitude using pretest and posttest methods. It also attempts to assess behavior change by observing whether learning translated into practice (Bates, 2004); (Frye and Hemmer, 2012). However, in most training practices, there is no real follow up study to assess the practical implementation or actual behavioral change. The effectiveness of any training program is largely dependent on the learners' ability to use 
their acquired knowledge and competencies on the job (Salas et al., 2006); (Grossman and Salas, 2011). In most organizations, training is carried out as the need arises, or when certain external events like Black Lives Matter protests demand change and action. The sustainability and long-term benefits of training activities can only be effectively assessed if the activity is part of the bigger organizational strategy with an ongoing assessment of intended organizational outcome. Meaningful assessment must measure both the learner capacity and willingness to learn (Luen and Al-Hawamdeh, 2001); (Wu et al., 2015). The alignment of individual values with that of the organization is necessary to be able to assess long-term behavioral change.

Most studies in knowledge management relevant to policing work focused on knowledge sharing and knowledge transfer as key factors in improving police work outcomes and operations effectiveness Adekannbi and Bello, (2021); Abrahamson and Goodman-Delahunty (2014); Seba and Rowley (2010); Luen and Al-Hawamdeh, (2001). However, several studies including Luen and Al-Hawamdeh in 2001 identify issues such as capacity to learn, willingness to engage in a learning process, and the competencies acquired through an effective knowledge transfer process. These studies identified that the key to successful implementation of knowledge management practices lies in recognizing the importance and value of tacit knowledge through skills, competencies, and the willingness of the police officers to engage in a meaningful and beneficial training exercise. This implies that those engaged in training must have the right attitude, motivation, and the level of trust to benefit from training activities. Figure 1 illustrates the process and the proposed framework for enhancing the capabilities and competency of Singapore Police officers. The study did not consider issues related to implicit or cultural bias and instead focused only on capacity building through effective knowledge transfer. The framework focused on three major areas including the capacity to learn, the willingness to learn, and the resources allocated to ensure successful training. 
Florianópolis, v. 9, n. 25, p. 06-30, 2020.

- ISSN 2316-6517 •

-DOI: $1047916 \cdot$

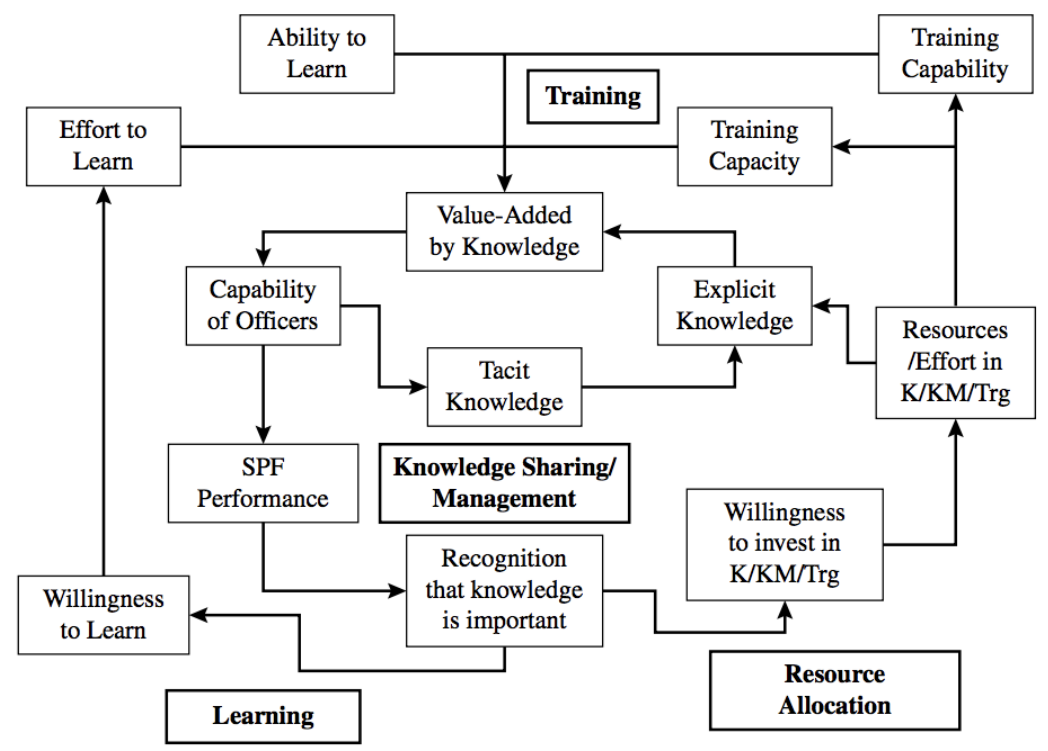

Figure 1 - Framework for enhancing the capability of police officers.

Knowledge processes such as knowledge creation, knowledge discovery, and knowledge transfer are critical to the development and success of any organization. At the heart of these activities is the conversion from one form of knowledge to another. The conversion from tacit knowledge to explicit knowledge and vice versa is considered people centric since tacit knowledge in the forms of skills and competencies resides within an individual and is normally shaped by cultural values, beliefs, norms and practices. The process by which tacit knowledge is transferred and acquired is illustrated in the SECI model developed by Nonaka and Takeuchi (1995). Nonaka and Takeuchi's knowledge creation model shown in Figure 2 consists of four different levels of knowledge conversion or interaction including socialization (tacit to tacit), externalization (tacit to explicit), combination (explicit to explicit), and internalization (explicit to tacit). Internalization and socialization are considered critical for effective knowledge transfer to take place. While the knowledge creation model is considered a significant milestone in the development of knowledge management, the model was criticized for being too abstract and for lack of empirical grounding (Glisby and Holden, 2003); (Gourlay, 2006); (Bratianu, 2010); (Farnese et al., 2019). 
Tacit knowledge in the form of memories and experiences are normally reflected in the organization's culture, values, norms, and practices, which directly influence information use and behavioral change (Taylor, 1991); (Davenport, 1997); (Choo et al., 2002).

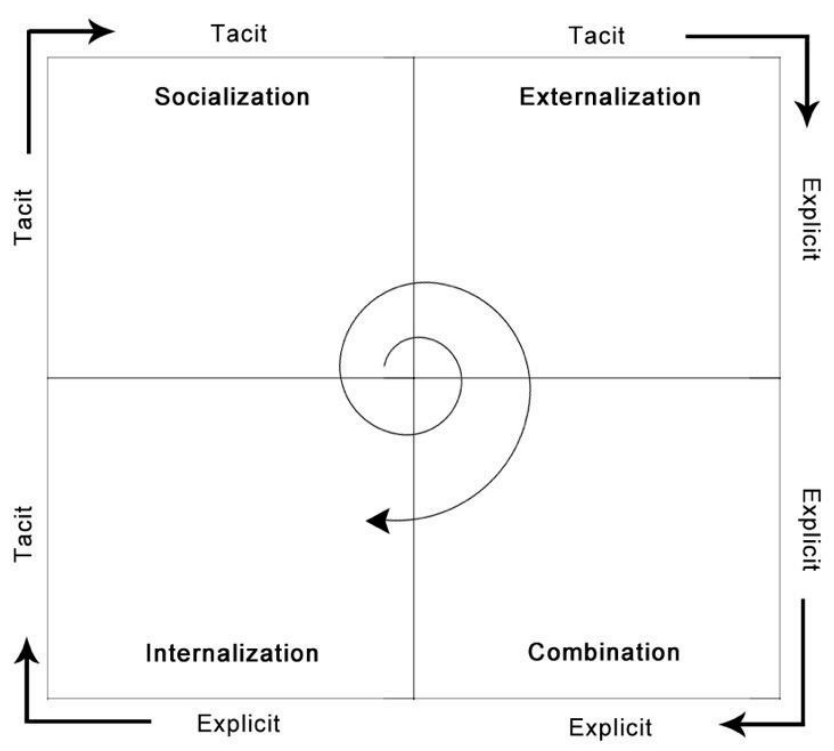

Figure 2 - SECl knowledge conversion model.

Choo et al. (2006) examined the information use environment of a large organization focusing on information use outcomes as a function of information culture and information management infrastructure. Cultural and structural issues in the form of norms, practices, values, strategies, roles, and regulations affected the attitudes of people in the organization and their willingness to engage in knowledge sharing and knowledge transfer activities. The two behavioral theories relevant to this topic that deal with attitude and behavioral change are the Theory of Reasoned Action (TRA) and the Theory of Planned Behavior (TPB). Both theories predict behavior change based on attitude, norms, and intention with theory of planned behavior introducing control beliefs that leads to perceived control (Fishbein and Ajzen, 1975); (Ajzen and Fishbein, 1980); (Ajzen, 1991); (Can and Hawamadeh, 2013). Ajzen (1985; 1991) argued that attitude, subjective norms, and perceived behavioral control influenced intention and ultimately 
behavior. The relevance of these theories stems from the fact that beliefs and subjective norms at the individual level intersect with the organizational norm and practices and in turn shape people's thinking, intentions, and actions. For example, implicit bias resulting from certain beliefs and subjective norms could eventually function as organizational bias or systemic bias.

Several adaptations of these theories and models were carried out by various studies Bock et al. (2005); Ibragimova (2006); Tao (2008). Bock et al.'s (2005) adaptation included organizational climate construct and motivational drivers in addition to attitude and subjective norms. In this study, the proposed framework in Figure 3 is based on behavioral theories with adaptation of the work by Choo et al. (2006) and by Luen and Al-Hawamdeh (2001). The proposed conceptual framework focuses on the cultural issues as well the structural issues such as organizational issues that affect attitude, capacity, and willingness to engage in activities such as learning. Attitude, capacity, and willingness affect intention and knowledge transfer activities. Evidence of knowledge transfer can predict actual behavior and imply behavioral change leading to the development of certain competencies such as cultural competence.

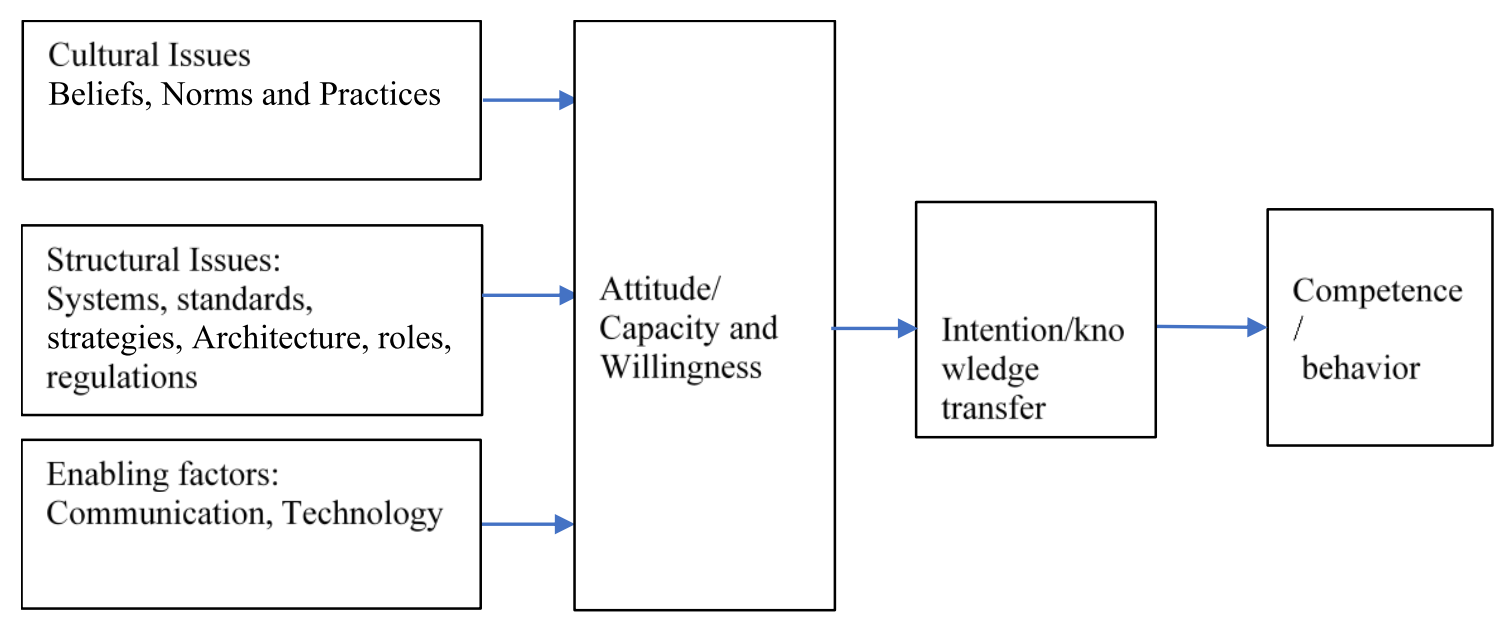

Figure 3 - Competence and behavioral Change Framework

The validation of the proposed model is being carried out as part of an ongoing mixed methods research using both quantitative and qualitative data analysis methods. The qualitative assessment will consider measures to assess tacit knowledge transfer 
Florianópolis, v. 9, n. 25, p. 06-30, 2020.

- ISSN 2316-6517 •

- DOI: 1047916 •

and behavioral change. One of the problems with social and cultural issues in policing is the lack of studies that deal with issues in a holistic and integrated framework. Preliminary results from content analysis of relevant studies retrieved from Google Scholar and Web of Science showed very little overlap among studies in terms of the concepts connecting the concepts implicit bias, cultural competence and tacit knowledge transfer. For each query using terms such as implicit bias, racial bias, cultural bias, systematic bias, diversity and inclusion, social competence, and cultural competence, we examined the top 50 hits and selected the studies that match at least one or more of these topics. Figure 4 shows the keyword clusters from studies on implicit bias in policing and Figure 5 shows the word clusters from studies on cultural competence in policing. It is clear from the two figures that there is very little overlap between these studies in terms of connecting the dots between implicit bias, racial or cultural bias, and cultural competence. In any implicit bias, racial or cultural bias training, the goal is to ensure effective knowledge transfer as a predictor for cultural competence and behavioral change.

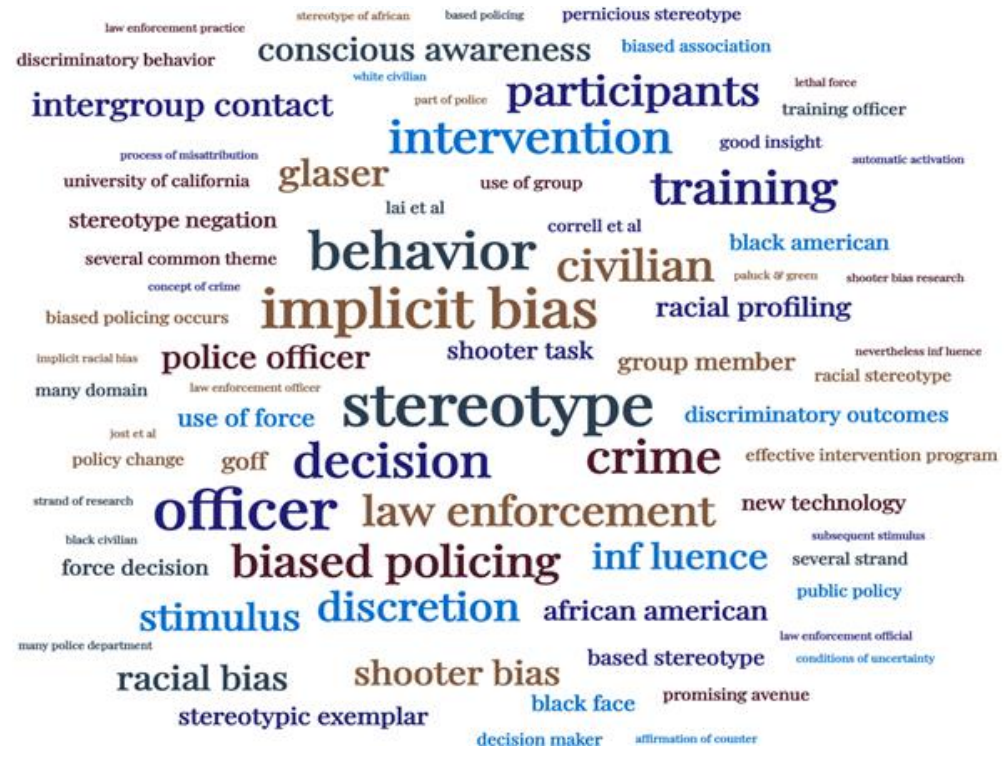

Figure 4 - Terms representations from studies on implicit bias. 
Florianópolis, v. 9, n. 25, p. 06-30, 2020.

- ISSN 2316-6517 •

- DOI: 1047916 •

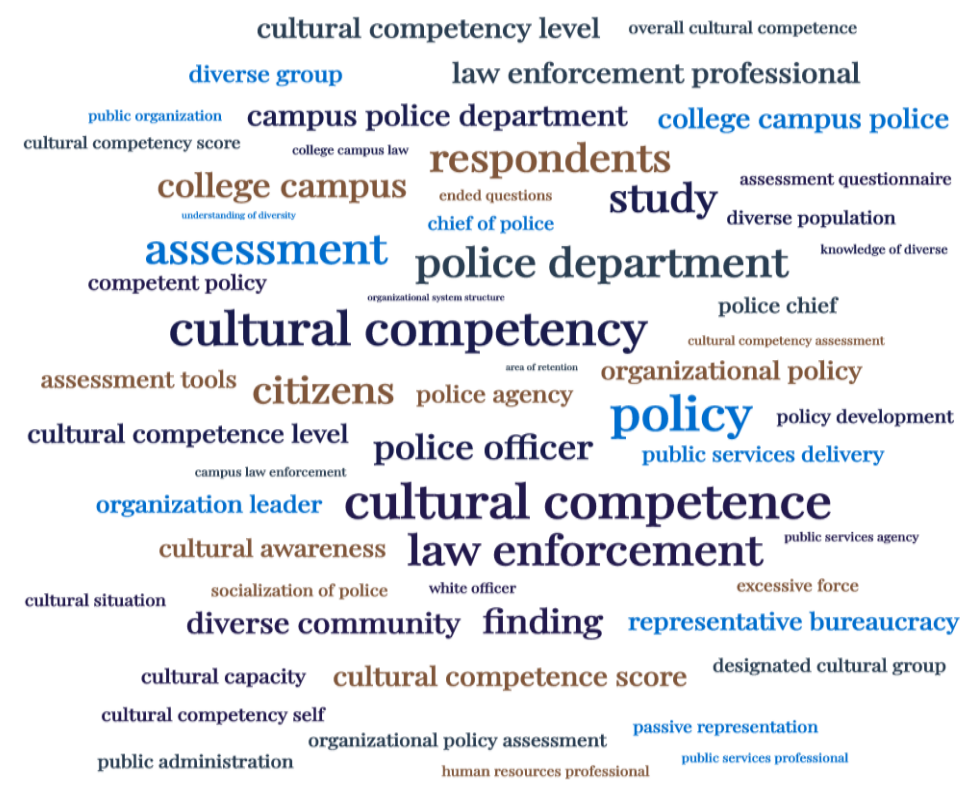

Figure 5 - Terms representations from studies on cultural competence.

\section{Conclusion and Future Work}

This paper discussed some of the cultural issues related to policing and social justice such as implicit bias, cultural bias, and cultural competence. The proposed conceptual framework emphasizes the importance of attitude, knowledge transfer, and intention as predictors of actual behavioral change. The recent events that followed George Floyd's death have ignited protests and highlighted the need for re-examining current policing practices and the social, cultural, and structural issues affecting police work. The work builds on previous work by Leun and Al-Hawamdeh (2001) emphasizing the importance of attitude, capacity building, and the willingness to engage in a meaningful learning and tacit knowledge transfer process. Content analysis of the literature in this area highlighted the need for a more holistic and integrated approach as well as the need to connect the dots between social, cultural, and structural issues. Technology as an enabler can be used to facilitate communication and enhance knowledge transfer activities. Police work is complex and requires highly trained individuals with a spectrum of skills and competencies including cultural competence. 
Florianópolis, v. 9, n. 25, p. 06-30, 2020.

- ISSN 2316-6517 •

- DOI: 1047916 •

Social and cultural competence are considered vital components of police work and need to be integrated into all police training. Future directions for this research are to conduct further investigations into the issues concerning effective tacit knowledge transfer and actual behavioral change. The results from the mixed methods research and the systematic content analysis of the literature will be used to assess the validity and reliability of the proposed model.

\section{References}

Abrahamson, D. E. and Goodman-Delahunty, J. (2014). Impediments to information and knowledge sharing within policing: A study of three Canadian policing organizations. SAGE Open, 4(1). DOI: https://journals.sagepub.com/doi/pdf/10.1177/2158244013519363

Adekannbi, J. O. and Bello, O. (2021). Factors Influencing Knowledge Sharing Behaviour of Police Officers in Ibadan Metropolis, Nigeria. Journal of Information and Knowledge Management, 20(02), $2150017 . \quad$ DOI: https://doi.org/10.1142/S0219649221500179.

Ajzen, I. (1991). The theory of planned behavior. Organizational Behavior and Human Decision Processes, 50(2), 179-211. DOI: https://doi.org/10.1016/07495978(91)90020- $\mathrm{T}$

Bates, R. (2004). A critical analysis of evaluation practice: the Kirkpatrick model and the principle of beneficence. Evaluation and program planning, 27(3), 341347. DOI: https://doi.org/10.1016/..evalprogplan.2004.04.011.

Braga, A. A. and Weisburd, D. L. (2007). Police innovation and crime prevention: Lessons learned from police research over the past 20 years. National Institute of Justice (NIJ) Policing Research Workshop: Planning for the Future. 
Washington, DC, November 28-29. https://nij.ojp.gov/library/publications/policeinnovation-and-crime-prevention-lessons-learned-police-research-over

Bransford, S. D. (2012). An examination of factors affecting information sharing among law enforcement agencies (Published On. 540) [Doctoral dissertations, University of Southern Mississippi]. AQUILA Campus Repository. https://aquila.usm.edu/dissertations/540/

Bratianu, C. (2010). A critical analysis of Nonaka's model of knowledge dynamics. Electronic Journal of Knowledge Management, 8, 193-200. Google Scholar

Burnett, S., Pedersen, S., Smith, R. and O'Neill, A. (2012). Venting, joining and educating: Motivations for knowledge sharing in the UK police blogosphere. Business Information Review, 29(1),

$57-$

63. https://doi.org/10.1177/0266382112438689.

Can, A. and Hawamdeh, S. (2013). Organizational Justice and the Intent to Share: Knowledge Sharing Practices among Forensic Experts in Turkey. Journal of Information Science Theory and Practice, 1(4), 12-37. DOI: https://doi.org/10.1633/JISTaP.2013.1.4.2

Choo, C. W., Furness, C., Paquette, S., van den Berg, H., Detlor, B., Bergeron, P. and Heaton, L. (2006). Working with information: information management and culture in a professional services organization. Journal of Information Science, 32(6), 491-510. https://doi.org/10.1177/0165551506068159

Coon, J. K. (2016). Police officers' attitudes toward diversity issues: Comparing supervisors and non-supervisors on multicultural skills, values, and training. International Journal of Police Science and Management, 18(2), 115125. https://doi.org/10.1177/1461355716643091. 
Curry, A. and Moore, C. (2003). Assessing information culture - An exploratory model. International Journal of Information Management, 23. 91-110. DOI: 10.1016/S0268-4012(02)00102-0

Davenport, T. H. (1997). Information Ecology: Mastering the Information and Knowledge Environment. Oxford University Press: New York. Google Scholar.

Dervin, B. (1983). An overview of sense-making research: concepts, methods, and results to date. Presented at: International Communication Association annual meeting, Dallas, May 1983. Google Scholar.

Engelman, A. and Deardorff, J. (2016). Cultural Competence Training for Law Enforcement Responding to Domestic Violence Emergencies With the Deaf and Hard of Hearing: A Mixed-Methods Evaluation. Health Promotion Practice, 17(2), 177-185. https://doi.org/10.1177/1524839915621538

Farnese, M. L., Barbieri, B., Chirumbolo, A. and Patriotta, G. (2019). Managing knowledge in organizations: A Nonaka's SECl model operationalization. Frontiers in psychology, 10, 2730. Google Scholar.

Fishbein, M. and Ajzen, I. (1975). Belief, attitude, intention, and behaviour: An introduction to theory and research. MA, Reading, Addison-Wesley.

Frye, A. W. and Hemmer, P. A. (2012). Program evaluation models and related theories: AMEE guide no. 67. Medical teacher, 34(5), e288-e299. https://doi.org/10.3109/0142159X.2012.668637 


\section{International Journal of Knowledge Engineering and Management}

Florianópolis, v. 9, n. 25, p. 06-30, 2020.

- ISSN 2316-6517 •

- DOI: 1047916 •

Gardiner, C. (2017). How educated should police be? National Police Foundation, www.policefoundation.org/study-examines-higher-education-inpolicing/ (2017, Accessed 13 March 2021).

Glisby, M. and Holden, N. (2003). Contextual constraints in knowledge management theory: the cultural embeddedness of Nonaka's knowledge creating company. Knowl. Process Manag, 10, 29-36. https://doi/10.1002/kpm.158

Gourlay, S. (2006). Conceptualizing knowledge creation: a critique of Nonaka's theory. Journal Management Studies, 43, 1415-1436. https://doi.org/10.1111/j.1467-6486.2006. 00637.

Greenwald, A. G., McGhee, D. E. and Schwartz, J. L. (1998). Measuring individual differences in implicit cognition: the implicit association test. Journal of personality and social psychology, 74(6), 1464-1480. https://doi.org/10.1037/0022-3514.74.6.1464

Grossman, R. and Salas, E. (2011). The transfer of training: what really matters. International Journal of Training and Development, 15(2), 103-120. https://doi.org/10.1111/j.1468-2419.2011.00373.x

Holmer, G and Deventer, F. (2014). Inclusive approaches to community policing and CVE. United States Institute of Peace Special Report, 352.

Luen, T. W. and Al-Hawamdeh, S. (2001). Knowledge management in the public sector: Principles and practices in police work. Journal of Information Science. 27(5), 311-18. https://doi.org/10.1177/016555150102700502

Mohammed Fathi, N., Cyril Eze, U. and Guan Gan Goh, G. (2011), Key determinants of knowledge sharing in an electronics manufacturing firm in 
Florianópolis, v. 9, n. 25, p. 06-30, 2020.

- ISSN 2316-6517 •

- DOI: 1047916 •

$\begin{array}{llll}\text { Malaysia. } & \text { Library } & \text { Review, } & \text { 50(1), }\end{array}$

67. https://doi.org/10.1108/00242531111100577

Plecas, D., McCormick, A.V., Levine, J., Neal, P. and Cohen, I.M. (2011). Evidence-based solution to information sharing between law enforcement agencies. Policing: An International Journal, 34(1). 120-134. https://doi.org/10.1108/13639511111106641

Rosellini, A. and Hawamdeh, S. (2020). Tacit knowledge transfer in training and the inherent limitations of using only quantitative measures. Proceedings of the Association for Information Science and Technology, 57(1), e272. https://doi.org/10.1002/pra2.272

Russell-Brown, K. (2018). The Academic Swoon Over Implicit Racial Bias. Du Bois Review, 15(1), 185-193. Google Scholar

Ryan, S. C. (2017). Police intelligence: connecting-the-dots in a network society. Policing and Society, 27(2), 173-187,

https://doi.org/10.1080/10439463.2015.1040794

Schlosser, M. (2011). Evaluating the Midwest Police Academy's ability to prepare recruits to police in a diverse multicultural society. Retrieved March 13, 2021, http://hdl.handle.net/2142/26225

Schlosser, M.D. (2013). Racial Attitudes of Police Recruits in the United States Midwest Police Academy: A Quantitative Examination. International Journal of Criminal Justice Sciences, 8, 215. Google Scholar 
Florianópolis, v. 9, n. 25, p. 06-30, 2020.

- ISSN 2316-6517 •

- DOI: 1047916 •

Seba, I. and Rowley, J. (2010). Knowledge management in UK police forces. Journal of Knowledge Management, 14(4), 611626. https://doi.org/10.1108/13673271011059554

Sereni-Massinger, C. and Wood, N. (2016). Improving law enforcement cross cultural competencies through continued education. Journal of Education and Learning, 5, 258, https://doi.org/10.5539/jel.v5n2p258.

Tarver, S. Z., Herring, M. H. and Friend, C. A. (2020) Implementation of an interdisciplinary cultural competence training with law enforcement personnel. Journal of Ethnic and Cultural Diversity in Social Work, 29(4), 251269, https://doi.org/ 10.1080/15313204.2019.1628682

Taylor, R.S. (1991). Information use environments. In: Dervin, B. and Voigt, M. J. (eds). Progress in Communication Science. Ablex Publishing: Norwood, NJ.

Telep, C. W. and Weisburd, D. (2012). What is known about the effectiveness of police practices in reducing crime and disorder? Police quarterly, 15(4), 331-357. DOI: https://doi.org/10.1177/1098611112447611

Torres, J., Reling, T. and Hawdon, J. (2018). Role conflict and the psychological impacts of the post-ferguson period on law enforcement motivation, cynicism, and apprehensiveness. Journal of Police and Criminal Psychology, 33(4), 358374. DOI: https://doi.org/10.1007/s11896-018-9284-y

Worden, R.E., McLean, S.J., Engel, R.S., Cochran, H., Corsaro, N., Reynolds, D., Najdowski, C.J. and Isaza, G. T. (2020). The impacts of implicit bias awareness training in the NYPD. The John F. Finn Institute for Public Safety/University of Cincinnati Center for Police Research and Policy. Google $\underline{\text { Scholar }}$ 
International Journal of Knowledge Engineering and Management

Florianópolis, v. 9, n. 25, p. 06-30, 2020.

- ISSN 2316-6517 •

- DOI: 1047916 •

Wu, Y. C., Hsieh, L. F. and Lu, J. J. (2015). What's The Relationship between Learning Satisfaction and Continuing Learning Intention?. Procedia-Social and Behavioral Sciences, 191, 2849-2854. DOI: https://doi.org/10.1016/j.sbspro.2015.04.148

Zimny, K. (2015). Racial attitudes of police recruits at the United States Midwest Police Academy: A second examination. International Journal of Criminal Justice $\begin{array}{llll}\text { Sciences, } & 10(1), & 91 & -101 .\end{array}$ https://www.sascv.org/ijcjs/pdfs/zimnyijcis2015vol10issue1.pdf 